\title{
Exploration of Transformational Leadership Practices and its Effect on Performance of Private Colleges: Mediating Role of Teachers' Retention
}

\author{
1 Muhammad Nadeem Anwar* ${ }^{2}$ Riffat un Nisa Awan ${ }^{3}$ Abida Parveen
}

1. Assistant Professor, Department of Education, University of Sargodha, Punjab, Pakistan

2. Associate Professor, Department of Education, University of Sargodha, Punjab, Pakistan

3. Lecturer, Department of Education, The University of Lahore, Sargodha Campus, Punjab, Pakistan

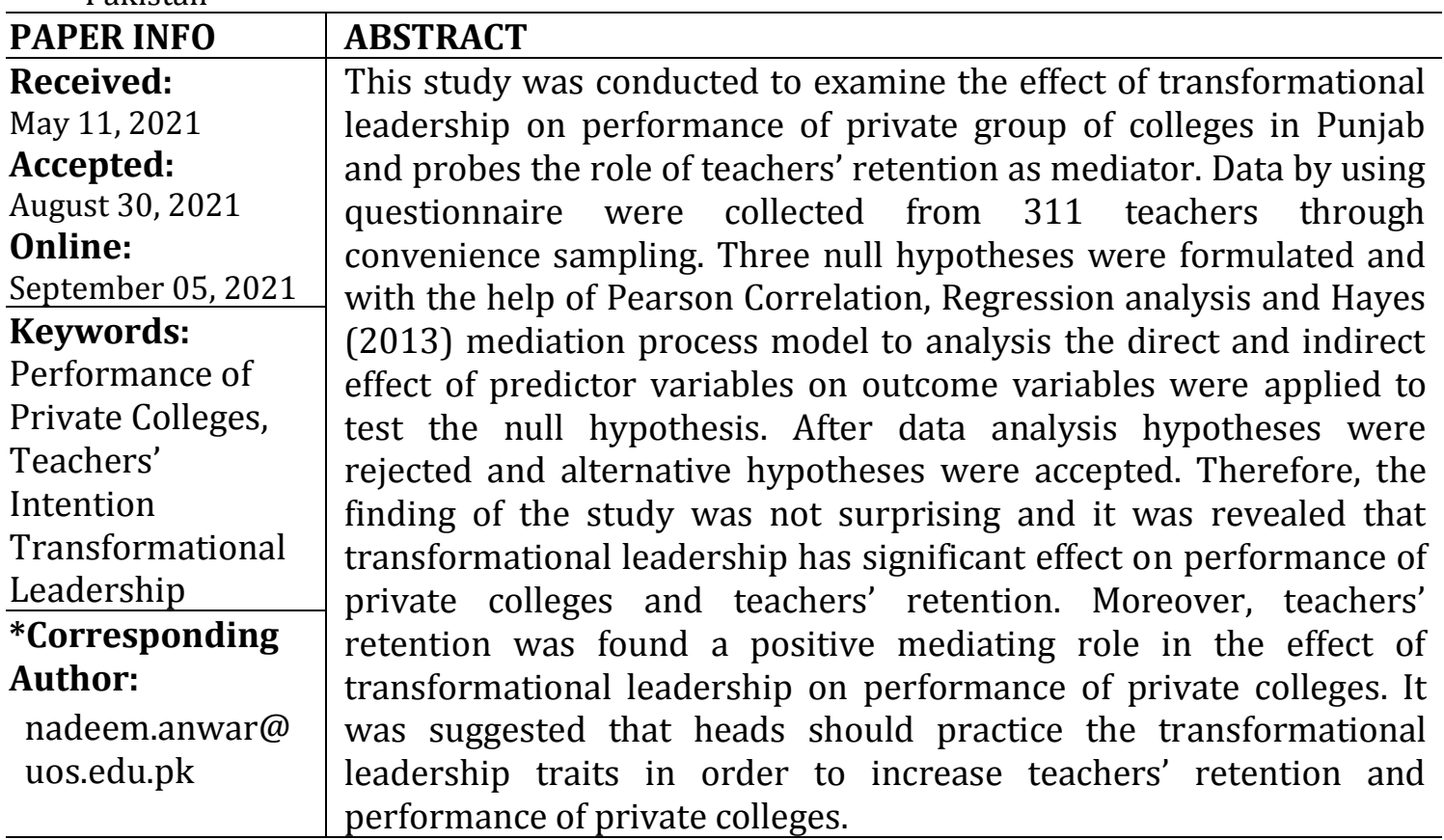

\section{Introduction}

In $21^{\text {st }}$ century, due to emergence of information and communication technology, rapid growth of social media and global competition have made the role of education crucial in the rise and fall of any nations. Awan (2011) explicated that like other countries Pakistan has public and private education system. However, in Pakistan, it has been observed that private education system is continuously grown up due to their better leadership, hardworking teaching staff, better physical resources, and particularly administration of test system. In Pakistan, overall, $40 \%$ of all educational institutions were private in 2020 21. In fact, the private education institutions are the profit making organizations, and owners include managerial functions in institutional management including finance, human resource, culture, public relationship and employees' behavior (Christian, Anastassia, \& Hansen, 2012). Therefore, due to this owner has entirely rely more on management 
particularly principals and provide support to him in hiring good faculty and creating conducive learning as well as study environment.

Leadership as concept plays significant role in the success of all kind of organizations private or public, educational or non-educational because it is vital function of management which exhausts the possibilities to efficiency of resources and effectiveness of organization. Hence private institutions require vibrant leadership who could play a very key role to manage the teachers and students in achievement of extraordinary results, communicate with teachers, and to manage material resources, generate and manage financial resources, and marketing prudently, furthermore they also have ability to build up cohesiveness among employees within the institution.

$\mathrm{Hu}$ (2001) stressed that group or individual behavior is greatly influenced by leadership to achieve organizational performances. Leadership, in fact, shape the strategies and influence others people in order to acquire full benefit. Organizational performance largely depends on effective leadership because leadership directly impacts on subordinate motivation, job satisfaction, job commitment, job retention. Regardless of any type either business or educational, leader is someone who initiating action, providing motivation \& guidance, creating confidence, building pleasant work environment, making co-ordination, creating more leaders, and managing insecurity about the changes.

Literature on leadership indicated that there are many leadership forms and constructs used to manage educational institution, including instructional, transformational, constructivist, servant, emotional, and transactional. Through plethora of researches, it has been seen that transformational leadership style has gained significant place because transformational leadership used to inspire, motivate, encourage and beneficial in transforming followers' self-concept and his personal values into organizational goals (Avolio et al., 1999).

Researches initiated in the field of education or other on transformational leadership are extensively interrelated to different behavioral aspects of teachers and their performance (Chan and Mak, 2014). Consequently, it's not amazing that the existing advancement in theory and practice on transformational leadership has fascinated the attention of educational researches as well as practitioners (Sahu, Pathadikar, \& Kumar, 2018).

\section{Literature Review}

Leadership is an ability to motivate and influence other people which leads towards the achievement of desired goals in a respectful and positive manner (de Oliveira Rodriguez \& Ferreira, 2015). There are various leadership practices could be used to motivate and influence such as behavioral, trait, transactional, situational, and transformational (Ghasabeh et al., 2015). However, leaders with transformational leadership traits have the ability to inspire co-workers to do their best. They develop their skills to advanced intellectual levels.

Transformational leadership can be stated that a leader who transforms the idealization into practical actions. Hu (2001) links transformation to organizational 
strategy and psychological aspects which can helpful in leading towards organizational change. Hay (2002) argues that transformational leadership is a type of leadership that does not concentrate on incentives against performance. The basic thrust is to develop the employees, encourage employees intellectually and fostering creatively and most importantly the transformation employees" own apprehensions into organization's mission. Transformational leadership is a leadership pattern used by leaders in order to change the existing situation through the identification of those who follow the organization's problems by inspiration, persuasion, and excitement to achieve a high level of clear vision for the purpose of recognizing common goals (Kirkan, 2011).

Transformational leaders have ability to create new ideas, new perspectives, new path of growth and prosperity. They continuously look for prospective motives in employees with aim at to draw their attention towards collective interests instead of their own needs, moreover transformational leader strive in conversion of individual interests into collective interest (Mirkamali et al., 2014).

\section{Distinguish Characteristics of Transformational Leaders}

While the explanation of transformational leadership given above helpful in understanding not only the process but to what extent it differs from other types of leadership. Some highlights about what has been noted are indicating below

1. In transformational leadership traits people affects their counterparts and superiors.

2. Values (one cannot bargain over them or exchange them) and personal beliefs (like justice, fairness, honesty, and honor) of the leader are entailed in the process of transformational leadership.

3. Transformational leaders build coherence and harmony among followers with the use of values and personal beliefs

4. Transformational leaders make changes in personal beliefs and goals of subordinates in line with organizational goals.

5. Inspiration from heart and mind can be seen in transformational leadership.

6. Transformational leaders have a particular perspective and eager to link it with purpose and passion.

7. Transformational leaders have much care regarding staff. They keep focus on what staff wants and how they can help out them. Consequently they win the trust and commitment of staff

8. Transformational leadership are proactive to learn innovative ideas and always.

\section{Theoretical Background and Hypothesis}

Due to outbreak of the COVID-19 pandemic, private colleges seek to maintain their survival that requires proactive leadership. Without sensible leadership who is 
aware of the nature of the administrative method to be used and important one is called transformational leadership (Alqatawenh, 2018) because transformational leadership plays imperative role in the individuals and group's performance (Bass, 1985).

Previous researches have analyzed that behavior of employees predicted by different factors and modified it by demonstration of different leadership types. Transformational leadership, in fact emphases on builds understanding among employees, focus on real-time problems, exploring new benchmarks, and motivates. Transformational leadership traits shape the behavior of employees to achieve organizational performance (Matwally \& El Zarka, 2017; Arif \& Akram, 2018). Since Bass (1985) work, many studies have been documented to seen effect of transformational leadership on behavioral aspects of employees e.g., motivation (Charbonneau et al. 2001), job satisfaction (Braun et al., 2013), organizational commitment (Avolio et at., 2004 and Wang et al., 2005), trust in a supervisor (Ahmad et al., 2008), job stress, as well as burnout (Flaschner et al.2006) and employees' turnover (Tse et al., 2013) etc.

Review of the literature suggests a head who demonstrates transformational leadership behaviors would foster positive behaviors with the faculty and staff. These behaviors could result in an increase in teachers' retention behavior. It has also seen that transformational leadership has impact on the performance of the organization (Wang et al., 2005 and Deinert et al., 2015). Individual or a group's behavior is highly influenced by leadership to achieve organizational performances (Hsu, 2001). Transformational leadership boosts individual as well as team performance (Mehdizadeh et al., 2018). Regardless of other leadership traits, the transformational leadership significantly plays better role in retaining employees that enhancing organizational performance (Covella et al., 2017). Leadership theories agreed that transformational leaders are more influential in modifying the behavior of employees (Burns, 1978), resulting is a good retention rate (Sow et al., 2016). Leaders having transformational features are help in developing retention in employees (Majeed et al., 2017).

Plethora of literature review highlighted that transformational leadership has effect on the performance of overall organization (Wang et al., 2005 and Deinert et al., 2015). Transformational leadership put efforts in improving employees' performance (Sow et al., 2016) by executing a reward system in order to retain them (Adekanbi, 2016). Multiple studies are indicating that transformational leadership enhances retention of employees' (Jiang et al., 2017) and overcome turnover intention (Maaitah, 2018). Therefore, based on above proclamation and comprehending of components of transformational leadership, a theoretical framework was proposed that retention of teachers (employees) plays a mediating role between direct effect transformational leadership on performance of private colleges. Therefore, researchers have developed following null hypothesis to check the claim:

Ho: There is no significant effect of transformational leadership on performance of private colleges

Ho: There is no significant effect of transformational leadership on teachers' retention 
Ho: There is no role of teachers' retention in mediating the effect of transformational leadership on performance of private colleges

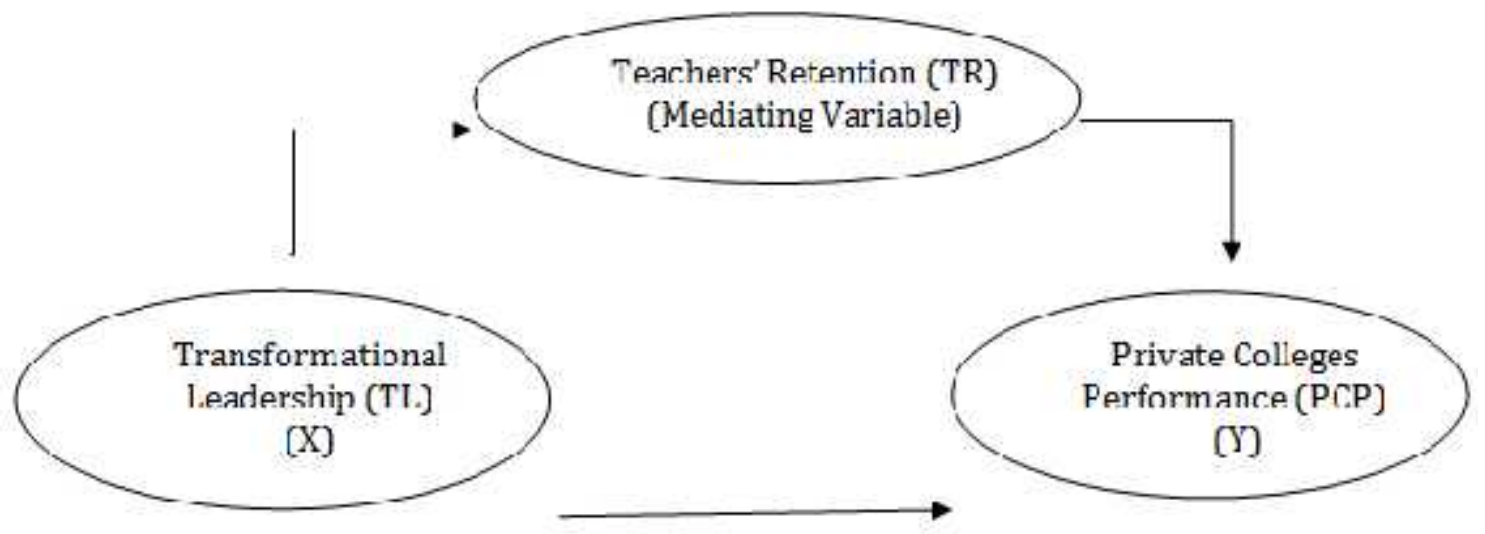

In above theoretical framework one independent variable $(X)$ called transformational leadership (TL), one dependent variable (Y) called performance of private colleges (PPC) or private colleges' performance (PCP), and teachers' retention (TR) was used as mediator variable.

\section{Material and Methods}

In present explanatory research relationship was determine between transformational leadership and performance of private colleges and examine the mediating role of teachers' retention between transformational leadership and performance of private colleges. Transformational leadership has sub dimensions but it taken as composite variable for the study. From the private college sector such as Punjab group of colleges and Superior group of colleges were selected for the study purpose. Teachers working in Punjab and Superior group of colleges operating in five big cities were the unit of investigation. Researcher has gathered data at one point in time for hypothesis testing therefore it was a cross sectional design.

\section{Population and Sampling}

Researcher has chosen Punjab group of colleges, and Superior group of colleges' teachers for this study working in Lahore, Gujranwala, Faisalabad, Rawalpindi and Sargodha cities of the Punjab, Pakistan, and that was considered as population. Teachers of Punjab and Superior group of colleges participated in this research study. Nonprobability i-e convenience sampling was used to collect data because the research was five cities based of Punjab and Superior group of colleges therefore the approach toward each teacher was convenient. A total of 350 teachers were contacted. From 324 questionnaires, 13 were overruled due to responses were incomplete and unclear. A total of $311(88.85 \%)$ rate of response was found. Data through self-developed questionnaires was collected by convenience sampling technique. 


\section{Research Instrument}

After extensive review of literature based on variables of the study a questionnaire was developed. Questionnaire comprised three parts one part was about transformational leadership, second part was consisted upon performance of colleges whereas third part used to collect data about teachers' retention. Overall questionnaire comprised 36 items constructed on five-point Likert scale and responses were ranging from strongly agree (SA) to strongly disagree (DSA). Reliability of questionnaire was determined and it was found to be 0.83 . For data collection, researcher has personally visited Lahore, Sargodha and Gujranwala and distributed the questionnaires among teachers of Punjab and Superior colleges. However researcher has posted questionnaires along with self-addressed envelope to the colleges of Faisalabad, Rawalpindi. Collected data was subsequently analyzed with the help of SPSS.

\section{Results and Discussion}

Table 1

Values of Cronbach's Alpha Coefficient

\begin{tabular}{ccc}
\hline Variables & No of Items & $\begin{array}{c}\text { Values of } \\
\text { Cronbach's Alpha }\end{array}$ \\
\hline Transformational Leadership (TL) & 12 & 0.819 \\
\hline Private Colleges Performance (PCP) & 10 & 0.825 \\
\hline Teachers' Retention (TR) & 12 & 0.855 \\
\hline
\end{tabular}

Table 1 depicts the values of Cronbach's Alpha Coefficient was found to be ranging from 0.819 to 0.855 . All values of Cronbach's Alpha show that all three parts of measuring tool good reliability and furthermore the values were significantly larger than the other studies conducted on the similar area.

Table 2

Correlation Analysis among variables

\begin{tabular}{|c|c|c|c|c|}
\hline Variables & & $\begin{array}{l}\text { Transformational } \\
\text { Leadership }\end{array}$ & $\begin{array}{l}\text { Teachers' } \\
\text { Retention }\end{array}$ & $\begin{array}{l}\text { Private Colleges' } \\
\text { Performance }\end{array}$ \\
\hline \multirow{3}{*}{$\begin{array}{l}\text { Transformational } \\
\text { Leadership }\end{array}$} & $\begin{array}{l}\text { Pearson } \\
\text { Correlation }\end{array}$ & 1 & & \\
\hline & Sig. (2-tailed) & & & \\
\hline & $\mathrm{N}$ & 311 & & \\
\hline \multirow{3}{*}{$\begin{array}{l}\text { Teachers' } \\
\text { Retention }\end{array}$} & $\begin{array}{l}\text { Pearson } \\
\text { Correlation }\end{array}$ & $.712^{*}$ & 1 & \\
\hline & Sig. (2-tailed) & 0.005 & & \\
\hline & $\mathrm{N}$ & 311 & 311 & \\
\hline \multirow{3}{*}{$\begin{array}{l}\text { Private Colleges' } \\
\text { Performance }\end{array}$} & $\begin{array}{l}\text { Pearson } \\
\text { Correlation }\end{array}$ & $0.747^{*}$ & 0.819* & 1 \\
\hline & Sig. (2-tailed) & 0.005 & 0.002 & \\
\hline & $\mathrm{N}$ & 311 & 311 & 311 \\
\hline
\end{tabular}

* Correlation is significant at the 0.05 level (2-tailed)

Above table 2 indicates that the value of correlation coefficient between transformational leadership and teachers' retention was found to be 0.712 . It shows a 
strong association between transformational leadership and teachers' retention. It means association is significant at .005. Similarly, the value of correlation coefficient between transformational leadership and private colleges' performance was found to be 0.747. It shows a strong positive association between transformational leadership and private colleges' performance. It means association is significant at .005.

Regression test was applied to test the hypothesis and to examine the effect of the independent variable on dependent variable and with the help of value of $\mathrm{R}$ square the regression analysis also indicates the fitness of model. Results are given in table 3.

Table 3

Regression Analysis of variables

\begin{tabular}{ccrrrrrr}
\hline No & \multicolumn{2}{c}{ Test } & B & T & R $^{2}$ & Adjusted R & F-test \\
\hline 1 & TL $\longrightarrow$ & PCP & 0.75 & $2.231^{* * *}$ & & & \\
\hline 2 & T L $\longrightarrow$ & TR & 0.41 & $6.507^{* * *}$ & 0.554 & 0.49 & 69.015 \\
\hline
\end{tabular}

Table 3 depicts that a relationship exist between transformational leadership (independent variable) and private colleges' performance (dependent variable). Teachers' Retention also found a significant effect on private colleges' performance. Transformational leadership was appeared economically and statistical role on Teachers' Retention at 5\% level of significance. Hence, it can be said that increase of one unit in practices of transformational leadership leads to 0.75 units increase in performance of private colleges. Therefore, the null hypothesis "there is no significant effect of transformational leadership on performance of private colleges" is rejected at $5 \%$ level of significance. Furthermore, one unit increase in transformational leadership leads to 0.41 units increase in teachers' retention. Therefore, the other null hypothesis "there is no significant effect of transformational leadership on teachers' retention" is rejected at 5 $\%$ level of significance.

\section{Mediation Analysis}

In order to analysis the direct and indirect effect of "predictor variables" on "outcome variables", Hayes (2013) has used in SPSS-21, in which he expressed that the mediation models can be explicated in model templates. In this study researcher, therefore, tested mediation on Process Models 4.

Table 4

Direct and indirect effect of Transformational Leadership (X) on Private Colleges' Performance (Y)

\begin{tabular}{cc}
\hline Variables & Direct effect of X on Y \\
\hline Transformational Leadership & $0.1948^{*}$ \\
\hline & -0.0561 \\
\hline Private Colleges' Performance & Indirect effect of X on Y \\
\hline & $0.0833^{*}$ \\
\hline Total effect & -0.0606 \\
\hline Portion of Mediating Variable & $0.1948+0.0833=0.2781$ \\
\hline
\end{tabular}


The table 4 shows the direct and indirect effect of independent variable (Transformational Leadership) on dependent variable (private colleges' performance) where $0.2995^{*}$ indicates that 29.95 (approximately 30\%) of the total effect of relationships explained by the mediator (Teachers' Retention). Therefore, the null hypothesis that "There is no role of teachers' retention in mediating the effect of transformational leadership on performance of private colleges" is rejected.

\section{Conclusion}

Purpose was conducted to examine the effect of transformational leadership practiced by Principals of private colleges on performance and mediating role of teachers' retention. At first, the effect of transformational leadership on performance of private colleges was measured. Secondly, examine the effect of transformational leadership on teachers' retention. And finally, it was assessed to what extent teachers' retention mediates the relationship of transformational leadership and performance of private colleges. Three null hypotheses were tested and after data analysis these hypothesis were rejected and alternative hypothesis were accepted. Therefore, it was concluded that in all cases a strong effect of transformational leadership practices on performance of private colleges and teachers' retention was recorded. With respect to performance of colleges the findings were appeared to be matched with findings of previous researches (Trmal et al., 2015; and Choudhary et al., 2013).

Moreover, it was also seen that teachers' retention mediates the relationship of transformational leadership and performance of private colleges, which means teachers' retention directly effects on performance of private colleges. If there will be high retention rate of teacher's means transformational leadership style effective and performance of private collegesis significantly high. As Giroux \& McLarney (2014) argues that transformational leadership improves the working environment which in turn leads a positive effect on employee retention and resulting in better outcomes for organizational performance. Additionally, study also expands that retention rate of teachers is increased if they enthusiastically provide academic support to colleagues and show loyalty toward the institution (Pickford and Joy, 2016 and Mittal and Kaur, 2018).

Therefore, precisely it can be inferred that this study in the favor of the use of transformational leadership because it support teachers in such a way that they are more loyal and observe high retention with institution and this leads positive influence performance of teachers and institution. Research findings proposed that training regarding on how to inspire, identify variety and individuality among group of teachers should be provided to the heads of the educational institutions. Findings are recommended that heads of the educational institutions should observant of the leadership traits and respect all teachers and this will yield a positive effect on the teachers who are involved in their teaching to give outstanding performance. This research should encourage research scholars to explore the possible impact of transformational leadership on organizational performance might be with different mediating variables. 


\section{References}

Abouraia, M. K. \& Othman, S. M. (2017). Transformational leadership, job satisfaction, organizational commitment, and turnover intentions: the direct effects among bank representatives. American Journal of Industrial and Business Management, 7(04), 404.

Adekanbi, A. (2016). An Investigation into the Impact of Leadership Styles on Employee Retention: Identifying which Leadership Style best encourages Employee Retention in the Nigerian Banking Sector: A Case study of Zenith Bank Plc. Nigeria (Doctoral dissertation, Dublin, National College of Ireland).

Alqatawenh, A. S. (2018). Transformational leadership style and its relationship with change management. Verslas: teorijairpraktika, 19(1), 17-24.

Arif, S. \&Akram, A. (2018). Transformational leadership and organizational performance: the mediating role of organizational innovation.SEISENSE Journal of Management, 1(3), 59-75.

Asgari, A. Silong, A. D. Ahmad, A. \&Samah, B. A. (2008). The relationship between transformational leadership behaviors, organizational justice, leader-member exchange, perceived organizational support, trust in management and organizational citizenship behaviors. European Journal of Scientific Research, 23(2), 227-242.

Avolio, B. J. Bass, B. M. \& Jung, D. I. (1999).Re-examining the components of transformational and transactional leadership using the Multifactor Leadership. Journal of occupational and organizational psychology, 72(4), 441-462.

Avolio, B. J. Zhu, W. Koh, W. \& Bhatia, P. (2004). Transformational leadership and organizational commitment: Mediating role of psychological empowerment and moderating role of structural distance. Journal of Organizational Behavior: The International Journal of Industrial, Occupational and Organizational Psychology and Behavior, 25(8), 951-968.

Awan, A.G. (2012) "Human Capital: Driving Force of Economic Growth in selected Emerging Economies" Global Disclosure of Economics and Business, Vol. 1 No.1.

Bass, B.M.(1985). Leadership and performance beyond expectation. London: Collier Macmillan.

Braun, S. Peus, C. Weisweiler, S. \& Frey, D. (2013). Transformational leadership, job satisfaction, and team performance: A multilevel mediation model of trust. The leadership quarterly, 24(1), 270-283. 
Burns, J. M. (1978). Leadership. New York: Harper \& Row.

Chan, S. C. \&Mak, W. M. (2014). Transformational leadership, pride in being a follower of the leader and organizational commitment. Leadership \& Organization Development Journal.

Charbonneau, D. Barling, J. \&Kelloway, E. K. (2001). Transformational leadership and sports performance: The mediating role of intrinsic motivation 1. Journal of applied social psychology, 31(7), 1521-1534.

Choudhary, A. I. Akhtar, S. A. \&Zaheer, A. (2013). Impact of transformational and servant leadership on organizational performance: A comparative analysis. Journal of business ethics, 116(2), 433-440.

Covella, G. McCarthy, V. Kaifi, B. \&Cocoran, D. (2017). Leadership's role in employee retention. Business Management Dynamics, 7(5), 1-15.

Deinert, A. Homan, A. C. Boer, D. Voelpel, S. C. \&Gutermann, D. (2015). Transformational leadership sub-dimensions and their link to leaders' personality and performance. The Leadership Quarterly, 26(6), 1095-1120.

Diaz-Saenz, H. R. (2011). Transformational leadership. The SAGE handbook of leadership, 5(1), 299-310.

Flaschner,A.B. Gill,A.S. \&Shachar,M. (2006). Mitigating Stress and burnout by implementating transformational leadership. International Journal of Contemporary Hospitality Management, 18(6), 469-481.

Ghasabeh, M. S. Soosay, C. \&Reaiche, C. (2015).The emerging role of transformational leadership. The Journal of Developing Areas, 49(6), 459-467.

Giroux, T. \&McLarney, C. (2014).Exploring the leadership continuum: The relevance of transformational leadership on organizational performance. Proceedings of the Northeast Region Decision Sciences Institute, 43(4), 862-886.

Gyensare, M. A. Kumedzro, L. E. Sanda, A. \&Boso, N. (2017).Linking transformational leadership to turnover intention in the public sector: The influences of engagement, affective commitment and psychological climate. African Journal of Economic and Management Studies. s, 8 (3). 314-337.

Hay, I. (2006). Transformational leadership: Characteristics and criticisms. E-journal of Organizational Learning and Leadership, 5(2), 1-19

$\mathrm{Hu}$, M. L. (2001). The relationship among organizational culture, transformational leadership, and job satisfaction: A study on seven southern governments' employees in Taiwan. 
Jiang, W. Zhao, X. \& Ni, J. (2017). The impact of transformational leadership on employee sustainable performance: The mediating role of organizational citizenship behavior. Sustainability, 9(9), 1567.

Maaitah, A. M. (2018). The role of leadership style on turnover intention. International Review of Management and Marketing, 8(5), 24.

Majeed, N. Ramayah, T. Mustamil, N. M. Nazri, M. \&Jamshed, S. (2017). Transformational leadership and organizational citizenship behavior: Modeling emotional intelligence as mediator. Management \& Marketing, 12(4), 571-590.

Matwally, A. Z. \& El Zarka, S. (2017). An understanding of transformational leadership and its implication on organizational learning: a literature review. Bus. Manag. Rev. 8, 163-168.

Mehdizadeh, S. ManzariTavakoli, A. Salajeghe, S. \&Sheikhi, A. (2018).Designing model of organizational citizenship behavior and health administrative" Issued by Supreme Leader" by mediator organizational spirituality. Iranian journal of educational Sociology, 1(8), 95-107.

Mirkamali, S. M. Vaezi, M. \&Tabar, M. S. (2014).The Relationship between Moral Intelligence and Team Leadership in Acecr of University of Tehran. Kuwait Chapter of the Arabian Journal of Business and Management Review, 3(12A), 192.

Mittal, D. K. and Kaur, N. (2018).Impact of organizational citizenship behavior on employee retention in banking sector. Int. J. Res. Eng. Appl. Manag. 3, 103-112.

Ombanda, P. O. (2015). The perceived relationship between employee retention practices and organization citizenship behaviour at DT Dobie (K) Ltd.

Pickford, H. C. \& Joy, G. (2016).Organisational Citizenship Behaviours: Definitions and Dimensions. NY: Social Science Research Network.

Rodrigues, A. D. O. \& Ferreira, M. C. (2015).The impact of transactional and transformational leadership style on organizational citizenship behaviors. PsicoUSF, 20, 493-504.

Sahu, S. Pathardikar, A. \& Kumar, A. (2017). Transformational leadership and turnover: Mediating effects of employee engagement, employer branding, and psychological attachment. Leadership \& Organization Development Journal.

Seetoo, D. H. (1999).Nonprofit organizations management. Taipei: Common Wealth.

Sow, M. Ntamon, A. \& Osuoha, R. (2016). Relationship between transformational leadership and employee retention among healthcare professionals in the United States. Business and Economic Research, 6(2), 235-254.

Trmal, S. A. Bustamam, U. S. A. \& Mohamed, Z. A. (2015). The effect of transformational leadership in achieving high performance workforce that exceeds organisational 
expectation: A study from a global and Islamic perspective. Global Business and Management Research, 7(2), 88.

Tse, H. H. Huang, X. \& Lam, W. (2014).“Why does transformational leadership matter for employee turnover? A multi-foci social exchange perspective”: Corrigendum.

Wang, H. Law, K. S. Hackett, R. D. Wang, D. \& Chen, Z. X. (2005).Leader-member exchange as a mediator of the relationship between transformational leadership and followers' performance and organizational citizenship behavior. Academy of management Journal, 48(3), 420-432. 